\title{
Teaching Model in Writing Indonesian for Advanced Foreign Speakers (Practical Study of Writing Skills for Foreign Speakers)
}

\author{
Titin Setiartin Ruslan ${ }^{1}$;Fikri Hakim ${ }^{2}$;Shinta Rosiana ${ }^{3}$ \\ 1, 2, ${ }^{3}$ Siliwangi University, Indonesia \\ 1titinsetiartin@unsil.ac.id; ${ }^{2}$ fikri.hakim@unsil.ac.id; \\ shinta.rosiana@unsil.ac.id
}

\begin{abstract}
The Indonesian Language Program for Foreign Speakers (BIPA) is a program that is being encouraged as an effort to implement a government program to make Indonesian (in this context: bahasa) as one of the international languages in 2045. Institutions of formal and non-formal education, both in government services and non-governmental organizations are starting to actively developed BIPA program. Teaching Indonesian for foreign speakers develops their own curriculum in the implementation of the programs. The main material developed is language skills material, including writing skills, language subsystems, literature, and Indonesian cultural material. Simply stated, after participating in the BIPA program, foreign speakers must understand at least the concept of listening, speaking, reading and writing in Indonesian. This research focuses on the teaching model of writing Indonesian. Writing is an integrated language skill, which is intended to produce something text or script. At least, there are three components that are incorporated into the act of writing, namely: (1) understand the written language (vocabulary, sentence structure, paragraphs, spelling, pragmatics, etc.); (2) understand the content (according to the topic to be written); and (3) understand the types of writing. This research used a descriptive qualitative method. The results of this study are alternative learning methods in fulfilling the competence of foreign speakers related to the ability to write using the process skills approach.
\end{abstract}

Keywords: Foreign, Language, Process skills approach

\section{PENDAHULUAN}

Indikator keterampilan berbahasa Indonesia setidaknya mencakup empat aspek, yakni membaca, menyimak, berbicara, dan menulis. Menulis termasuk pada aspek keterampilan yang bersifat produktif. [11] mendefinisikan menulis sebagai wujud komunikasi verbal dengan memanfaatkan media berupa simbol-simbol tulis. Graves (dalam [11]) menyatakan bahwa menulis bermanfaat dalam proses mengembangan kecerdasan, mengembangkan daya inisiatif dan kreativitas, menumbuhkan rasa percaya diri, serta yang paling utama menulis dapat meningkatkan kemampuan dalam menemukan, mengumpulkan, mengolah, hingga mengorganisasikan segala bentuk informasi.

Sebagai satu di antara indikator keterampilan berbahasa Indonesia, keterampilan menulis menjadi satu di antara keterampilan yang wajib dikuasai oleh pemelajar bahasa Indonesia, termasuk penutur asing. Untuk menjadi penulis, selain mempelajari teori menulis, juga harus mempraktikkannya (memproduksi tulisan). Frekuensi latihan menulis berpengaruh pada tingkat 
kemahiran menulis seseorang. Bagi penutur asing, diperlukan model atau metode pembelajaran yang tepat guna memenuhi kompetensi keterampilan menulis. Sebagian besar penutur asing yang mempelajari bahasa Indonesia di-treatment dengan pendekatan tradisional yang berorientasi pada aspek yang bersifat materi atau teoretis, bukan pada asspek praktis. Hal tersebut terepresentasi dalam penelitian [10].

Ketidakefektifan penggunaan model atau metode tradisional dalam mencapai indikator keterampilan berbicara bahasa Indonesia (bagi) penutur asing dipaparkan oleh [10]. Alternatif model yang ditawarkan [10], yakni dengan pendekatan proses (diadaptasi dari [9]) yang berorientasi pada sisi praktis. Pendapat [7] juga menyatakan bahwa pendekatan keterampilan proses dalam kompetensi menulis akan efektif digunakan untuk pemelajar dengan karakter tertentu. Dalam kaitannya dengan proses pembelajaran, [9] menyatakan bahwa pengajar harus lebih berperan dominan pada tahap pembimbingan dalam proses menulis secara praktis. Tahapan terkait proses menulis yang berorientasi proses disampaikan [9]. Tahapan-tahapan tersebut yakni, (1) persiapan (pramenulis), (2) pembuatan draft, (3) revisi, (4) penyuntingan, dan (5) berbagi (sharing). Sejalan dengan [9], [4] juga menawarkan suatu konsep pengembangan keterampilan menulis. Menurut Nunan, menulis dianggap sebagai suatu proses dan menulis sebagai suatu produk. Hal tersebut melatarbelakangi peneliti untuk melakukan kajian pustaka terhadap konsep yang ditawarkan Tompkins dan Nunan. Peneliti berfokus pada modifikasi tahapan proses menulis yang dipaparkan Tompkins dengan berorientasi pada produk (konsep pengembangan Nunan). Hasil kajian pustaka yang peneliti lakukan juga dapat dijadikan alternatif model pembelajaran yang tepat untuk kompetensi menulis bagi penutur asing.

\section{METODE PENELITIAN}

Penelitian ini merupakan penelitian kualitatif deskriptif berupa kajian pustaka yang menawarkan model dan pendekatan alternatif dalam pembelajaran menulis pada pemelajar BIPA. Data berupa komparasi pendekatan tradisional dan pendekatan proses ditampilkan, untuk kemudian dikaji lebih jauh keefektifannya dalam proses pembelajaran menulis. Penelitian diakhiri dengan penarikan simpulan/verifikasi. Simpulan dihasilkan dari kajian terhadap model atau pendekatan yang dirasa cocok digunakan dalam pembelajaran menulis pada pemelajar BIPA.

\section{HASIL DAN PEMBAHASAN}

Berdasar pada Peraturan Menteri Pendidikan dan Kebudayaan RI Nomor 27 Tahun 2017 (selanjutnya disebut Permendikbud No. 27 Tahun 2017), peneliti memutuskan indikator penutur asing tingkat lanjut atau advanced adalah penutur yang masuk kategori kelas BIPA 7. Berdasar pada Permendikbud No. 27 Tahun 2017, pemelajar BIPA 7 dianggap sudah paham akan informasi hampir pada semua bidang. Hal tersebut terepresentasi dalam kemampuan mengungkapkan gagasan secara spontan, tepat, benar, tanpa hambatan berarti, dan mampu mengidentifikasi berbagai macam nuansa makna, serta merekonstruksi argumen dalam konstruksi bahasa yang kohesif dan koheren. Terkait kompetensi menulis, dalam Permendikbud No. 27 Tahun 2017 pemelajar BIPA 7 diharapkan mampu memproduksi tulisan yang kohesif dan koheren, sesuai dengan tujuan dan target pembaca, baik fiksi maupun nonfiksi, termasuk teks akademik. Indikator dari kompetensi tersebut terbagi atas (1)menulis teks narasi secara kohesif dan koheren; (2)menulis berbagai teks nonfiksi populer yang berupa eksplanasi secara kohesif dan koheren; (3)penulisan berbagai teks nonfiksi populer yang berupa eksplanasi secara kohesif dan koheren; (4)penulisan berbagai teks nonfiksi dalam bentuk laporan kegiatan, 
pengamatan, dan penelitian secara kohesif dan koheren. Mengacu pada kompetensi dan indikator tersebut, peneliti merumuskan alternatif model pembelajaran menulis dalam pemelajar BIPA 7.

\subsection{Pendekatan Tradisional vs. Pendekatan Keterampilan Proses}

Pendekatan tradisional lebih berorientasi pada materi dan teori ketimbang pada aspek praktis. Berbeda dengan pendekatan keterampilan proses yang berorientasi pada proses praktis pemelajar dalam memproduksi tulisan. Dalam pendekatan tradisional, proses pembelajaran konvensional yang cenderung dilakukan. Pengajar memaparkan materi dan teori terkait jenis tulisan, definisi tulisan, organisasi tulisan, dsb. Hal tersebut akan tepat saat pemelajar sudah memiliki kognisi yang sejalan dengan pengajar. Terlebih lagi, saat penugasan, topik atau tema yang diangkat dalam pendekatan tradisional lazimnya ditentukan oleh pengajar, sehingga semua pemelajar atau peserta didik menghasilkan tulisan yang relatif mirip.

Berkaitan dengan tahapan menulis yang disinggung pada pendahuluan, Tompkins memaparkan bahwa tahapan-tahapan tersebut bersifat fleksibel dan dinamis. Hal tersebut dapat dimaknai bahwa tahapan-tahapan tersebut tidak harus selalu linear dari mulai persiapan hingga tahap sharing. Saat sudah masuk tahap revisi, penulis dimungkinkan untuk kembali pada tahap persiapan ataupun penulisan draft. Hal tersebut disesuaikan dengan kebutuhan dan proses menulis yang berlangsung.

Peneliti telah melakukan modifikasi terhadap tahap-tahap yang ditawarkan Tompkins. Modifikasi tersebut disesuaikan dengan kebutuhan pemelajar, dalam hal ini penutur asing. Berikut ini peneliti paparkan perbandingan pendekatan tradisional dan hasil modifikasi pendekatan keterampilan proses dalam pencapaian kompetensi menulis bahasa Indonesia bagi penutur asing.

Tabel 1

Pendekatan Tradisional vs. (Modifikasi) Pendekatan Keterampilan Proses dalam Menulis No. Pendekatan Tradisional Tahapan Pendekatan Keterampilan Proses

\begin{tabular}{|c|c|c|c|}
\hline 1. & $\begin{array}{l}\text { Tugas menulis kreatif secara } \\
\text { spesifik diberikan oleh } \\
\text { pengajar. }\end{array}$ & Pramenulis & $\begin{array}{l}\text { Pemelajar dibebaskan memilih } \\
\text { topik sesuai yang diinginkan. } \\
\text { Memungkinkan pemelajar untuk } \\
\text { memilih topik yang relative "dekat" } \\
\text { dengan mereka. }\end{array}$ \\
\hline 2. & $\begin{array}{l}\text { Pengajar memberikan } \\
\text { materi yang berfokus pada } \\
\text { teks (bukan pada proses } \\
\text { menulis). Pemelajar } \\
\text { diharapkan mampu menulis } \\
\text { sebaik-baiknya sesuai } \\
\text { materi yang diberikan. }\end{array}$ & & $\begin{array}{l}\text { Pengajar memberikan materi terkait } \\
\text { proses menulis dan jenis tulisan } \\
\text { untuk kemudian dikembangkan } \\
\text { lebih jauh oleh pemelajar. }\end{array}$ \\
\hline 3. & $\begin{array}{l}\text { Berfokus pada (contoh) } \\
\text { tulisan yang sudah jadi. }\end{array}$ & & Berfokus pada proses. \\
\hline 4. & $\begin{array}{l}\text { Hanya sedikit atau tidak ada } \\
\text { kerja sama antar pemelajar. }\end{array}$ & $\begin{array}{l}\text { Pembuatan } \\
\text { draft }\end{array}$ & $\begin{array}{l}\text { Pemelajar dituntut untuk dapat } \\
\text { bekerja sama, saling tukar } \\
\text { pendapat, saling revisi, guna }\end{array}$ \\
\hline
\end{tabular}




\begin{tabular}{ll}
\hline 5. & $\begin{array}{l}\text { Pemelajar menulis } \text { draft } \\
\text { tunggal yang berorientasi } \\
\text { pada struktur kebahasaan } \\
\text { (jenis tulisan, ejaan, tata } \\
\text { bahasa, dsb.) }\end{array}$ \\
\hline 6. & $\begin{array}{l}\text { Pemelajar dituntut untuk } \\
\text { mampu memproduksi } \\
\text { tulisan yang bebas dari } \\
\text { kesalahan berbahasa dalam } \\
\text { waktu yang relatif singkat. }\end{array}$ \\
\hline 7. & $\begin{array}{l}\text { Waktu penyelesaian tulisan } \\
\text { berpatok pada jam kelas. } \\
\text { (relatif singkat) }\end{array}$ \\
\end{tabular}

8. Pengajar memberikan tugas menulis dan melakukan evaluasi ketika tulisan sudah rampung.

9. Evaluasi berfokus pada halhal yang bersifat teoretis. menghasilkan tulisan yang lebih representatif.

Pemelajar menulis draft kasar (outline) untuk menuangkan gagasan dan kemudian merevisi dan menyunting draft ini sebelum membuat hasil akhir.

Pemelajar mengoreksi sendiri tulisan yang dibuat dengan berdiskusi bersama ataupun konsultasi pada pengajar, hingga muncul solusi terbaik.

Waktu penyelesaian tulisan dibuat lebih longgar, dalam artian pemelajar boleh menyelesaikan tulisan di luar jam pembelajaran.

Tahap revisi Pengajar mendampingi dan sesekali (sekaligus) mengingatkan terkait teori atau penyuntingan. materi sembari memberikan umpan balik selama pemelajar merevisi dan mengedit/menyunting.

Evaluasi difokuskan pada proses dan hasil tulisan. Selain itu, pemelajar dapat berdiskusi dengan pemelajar lain terkait tulisan masing-masing. Pendekatan ini lebih bersifat praktis.

10. Kurangnya rasa memiliki Berbagi Pemelajar merasa memiliki tulisan sendiri karena mulai dari penentuan topik, jenis tulisan, dsb., pemelajar dibebaskan untuk memilih. Pengajar hanya sebatas mengarahkan. pemelajar karena mulai dari jenis tulisan, hingga topik ditentukan oleh pengajar.

11. Pengajar merupakan pembaca utama.

Hasil tulisan pemelajar menulis untuk pembaca yang sesungguhnya (tidak hanya untuk pengajar semata).

Tulisan memungkinkan untuk dibagikan dalam ruang lingkup yang lebih luas. Pengajar memberikan arahan untuk berani memasukkan tulisan hasil karya pemelajar ke wadah-wadah literasi seperti media (koran, blog, dsb.) ataupun jurnal-jurnal ilmiah (jika tulisan yang dihasilkan berformat artikel ilmiah). 
Dari tabel tersebut, dapat diketahui kelemahan dan keunggulan masing-masing pendekatan. Secara umum, pendekatan tradisional terlalu "mengekang" pemelajar. Mengekang dalam artian mulai dari teori, jenis tulisan, topik, dsb., ditentukan oleh pengajar. Hal tersebut dapat menjadi hambatan yang serius, terutama bagi penutur asing. Berdasar pada pengalaman dalam memberikan proses pembelajaran terhadap penutur asing, teridentifikasi bahwa hanya sebagian kecil pemelajar yang mampu menghasilkan tulisan yang baik dan benar. Dalam kondisi tersebut, pemelajar tidak mempelajari bagaimana cara menulis. Sebagian besar pemelajar dihadapkan pada "teori" dan kesulitannya mengaplikasikan teori tersebut dalam proses menulis mereka. Model/pendekatan keterampilan proses dalam pembelajaran menulis bisa menjadi alternatif solusi dalam pencapaian kompetensi keterampilan menulis bahasa Indonesia bagi penutur asing.

\subsection{Menulis sebagai Proses Kreatif}

Menurut [7], menulis merupakan suatu proses kreatif yang banyak melibatkan cara berpikir divergen (menyebar) daripada konvergen (memusat). Layaknya pelukis dengan lukisannya, penulis memiliki banyak gagasan dalam setiap tulisannya. Kendatipun secara teknis ada kriteria-kriteria yang dapat diikutinya, tetapi wujud yang akan dihasilkan itu sangat bergantung pada kepiawaian penulis dalam mengungkapkan gagasan. Banyak orang mempunyai ide dan gagasan hebat sebagai hasil dari observasi yang mendalam. Namun, saat ide tersebut direpresentasikan dalam bentuk tulis, tulisan yang dihasilkan tidak dapat merepresentasikan dengan sempurna ide dan gagasan hebat tadi. Banyak hal yang berpengaruh mulai dari sudut pandang, diksi, hingga variasi bahasa yang digunakn. Hal-hal tersebut menunjukkan bahwa menulis merupakan proses kreatif yang membutuhkan keahlian dan nilai rasa layaknya seni.

Sebagai proses kreatif, menulis berada pada ruang lingkup kognitif. Proses kreatif dalam menulis dipengaruhi kognisi seorang penulis. Oleh karena itu, akan sangat sulit saat penutur asing dituntut untuk dapat menguasai kompetensi menulis bahasa Indonesia dengan pendekatan tradisional. Dalam pendekatan keterampilan proses, pemelajar dalam hal ini penutur asing dibebaskan untuk memilih topik yang "dekat" dengan mereka. Kedekatan topik tentu dipengaruhi latar belakang dan kognisi pemelajar, [3] menyatakan bahwa kognisi seseorang berpengaruh terhadap hasil tulisan yang diproduksinya. Selain itu, [3] juga menyatakan kecenderungan pembaca akan memilih bacaan yang dekat secara "kognisi". Pemelajar juga dibebaskan memilih jenis tulisan dan sasaran tulis yang dituju. Hal tersebut akan mampu meningkatkan daya kreativitas pemelajar.

\subsection{Proses Pembelajaran Menulis}

Kelima tahapan yang dipaparkan [9] dapat direpresentasikan dalam berbagai bentuk. Secara garis besar, pengajar cukup memberi pengetahuan awal berupa jenis tulisan dan karakter tulisan. Selanjutnya pengajar cukup mendampingi pemelajar dan mengarahkan jika ada pertanyaan dari pemelajar. Pembelajaran berfokus pada produk, yakni tulisan. Oleh karena itu, biarkan pemelajar yang berperan dominan dalam proses kreatif tersebut. Biarkan pemelajar larut dalam proses kreatif. Pengajar tidak perlu menentukan topik hingga mengatur jenis tulisan. Perbedaan kognisi dan latar belakang sosial budaya akan menjadi penghambat jika pengajar memaksakan suatu tema atau topik yang "jauh" dari pemelajar [12]. 


\section{SIMPULAN}

Salah satu alternatif pendekatan dalam proses pembelajaran terkait kompetensi keterampilan menulis bagi penutur asing (yang direpresentasikan oleh siswa BIPA 7) adalah pendekatan keterampilan proses. Pendekatan keterampilan proses menulis bahasa Indonesia merupakan alternatif yang peneliti tawarkan guna terciptanya hasil tulisan yang sesuai standar. Pendekatan proses keterampilan menulis mulai dari tahap persiapan hingga berbagi dapat memacu proses kreatif pemelajar sekaligus menghasilkan proses pembelajaran yang lebih efektif. Hasil tulisan akan beragam, pemelajar juga merasa lebih memiliki tulisan mereka karena "kedekatan" topik yang sejak awal dibangun.

\section{REFERENCES}

[1] Andayani, "Integrasi Model Pemahaman Budaya Lokal Dalam Pembelajaran Bahasa Indonesia Bagi Penutur Asing Dengan Pendekatan Integratif," in Seminar Nasional dan Launching ADOBSI, 2011, no. 10, pp. 219-223.

[2] Asqina Mawadati N.S; Andayani; Kundharu Saddhono, "Pembelajaran Menulis Pada Mahasiswa Bipa: Analisis Tentang Hambatan Dan Solusi," in CLLT: Conference on Language and Language Teaching, 2017, pp. 551-555.

[3] F. Hakim, N. Darmayanti, and A. Rachmat, "Pemberitaan Konflik antara Viking dan Jakmania dalam viva . co . id : Suatu Kajian Wacana Kritis," J. Linguist. Terap., pp. 38, 2018.

[4] D. Nunan, Language Teaching Methodology. New York: Prentice Hall, 1991.

[5] R. Ramadhani, W. Hs, and T. Harsiati, "Pengembangan Bahan Ajar Keterampilan Berbicara Bahasa Indonesia Bagi Penutur Asing Tingkat Pemula," J. Pendidik. - Teor. Penelitian, dan Pengemb., vol. 1, no. 3, pp. 326-337, 2016.

[6] Ruskhan Gaffar Abdul, "Pemanfaatan Keberagaman Budaya Indonesia Dalam Pengajaran Bahasa Indonesia,” Semin. Pengajaran Bhs. Indones. Pertem. Asos. JepangIndones. di Nanzan Gakuen Train. Cent., no. November, pp. 1-4, 2007.

[7] D. Supriadi, Isu dan Agenda Pendidikan Tinggi di Indonesia. Jakarta: PT Rosda Jayaputra, 1997.

[8] I. Suyitno, "Norma Pedagogis Dan Analisis Kebutuhan Belajar Dalam Pembelajaran Bahasa Indonesia Untuk Penutur Asing (Bipa)," Diksi, vol. 15, no. 1, pp. 111-119, 2015.

[9] G. Tompkins, Teaching Writing Balancing Process and Product. New York: Macmillan Publishing Company, 1990.

[10] Y. Wahyono, Tri; Farahsani, "Penerapan Pendekatan Proses Untuk Meningkatkan Keterampilan Berbicara Bahasa Indonesia Bagi Penutur Asing," AKSIS J. Pendidik. Bhs. dan Sastra Indones., vol. 1, pp. 204-220, 2017.

[11] M. Yunus, Keterampilan Menulis. Tangerang: Universitas Terbuka (press), 2014.

[12] K. Saddhono, A. Hasibuan, and M. I. Bakhtiar, "Facebook as A Learning Media in TISOL (Teaching Indonesian to Speakers of Other Languages) Learning to Support The Independency of Foreign Students in Indonesia," in Journal of Physics: Conference Series, 2019, vol. 1254, no. 1, p. 12061. 